\author{
Ewa Waryś \\ Cracow University of Technology \\ Institute of Landscape Architecture \\ ul. Warszawska 24 \\ 31-155 Kraków \\ ewawarys@wp.pl
}

\title{
ARCHITECTURAL OBJECTS AND PUBLIC SPACES CONNECTED WITH INDUSTRY. A CONTRIBUTION TO THE DISCUSSION ON ARTISTIC AND AESTHETIC VALUES
}

\begin{abstract}
The article presents the contemporary cultural landscape of the historical workers' settlements, located within the current administrative boundaries of the city of Katowice. Selected building complexes are standardized in terms of typology and building design, but differ in terms of the conservation status and forms of protection. The aim of the discussion is to show the relationship between the artistic and architectural aesthetics and public spaces related to the industry. The subject matter is an attempt to draw attention to the problem of the conservation status of most parts of the historical complexes of residential buildings in Upper Silesia, their untapped potential and declining values.
\end{abstract}

Keywords:

public space, post-industrial city, values of architecture

\section{INTRODUCTION}

The cultural landscape of cities related to the industry, especially those located in the Upper Silesian Industrial Region, for years was seen as an area devoid of artistic value. ${ }^{1}$ Although now people increasingly emphasize the significance and importance of the cultural heritage of the industrial age, there is still a significant proportion of valuable architectural and urban structures that are in poor condition, impeding noticing the values and potential hidden in them. In

\footnotetext{
${ }^{1}$ Barbara Szczypka-Gwiazda, Pomiędzy praktyka a utopia: trójmiasto Bytom - Zabrze - Gliwice jako przykład koncepcji miasta przemystowego czasów Republiki Weimarskiej (Katowice: Wydawnictwo Uniwersytetu Śląskiego, 2003), 7.
} 
the discussion on the issue of the cultural heritage of the industrial era, one drew attention to the issue of urban art, presented in both contemporary and historical terms. One has defined the importance of factors that determine the artistic value of individual objects and entire urban structures. In the presented approach, the role of urban creators is played by architects and designers of public spaces who, through their actions, bring art elements in the landscape of the city and create space for the development of other fields of artistic creation. The author also presented contemporary attempts to continue old traditions, inspired by the historic landscape, materialized among others in the latest architectural realizations, created within the modern cities.

\section{METHODS}

In order to show the relationship between the artistic value an aesthetics of cultural landscape of the housing complexes related to the industry, analysis on the state of preservation of historical buildings of residential buildings and the quality of public spaces was carried out. The scope of the research included two housing estates, located within the current administrative borders of Katowice: Katowice-Załęże and Nikiszowiec, included in the administrative area of Janów-Nikiszowiec. The criterion for selection of examples for the analysis was the typology and design of buildings. Workers' houses located in the area of both settlements have been built as multi-family buildings, so-called familoki. One has compared the location of both of them with respect to functional and spatial structure and transport system of the city, artistic value and state of preservation of architectural objects, readability of urban systems and the quality of public spaces. Background research for the above analysis provides a general outline of the development of industrialization and development of the residential centers in Upper Silesia. In the final part of the paper, one presented contemporary forms of artistic expression, which now often appear in the industrial landscape. The author has also presented contemporary examples of architectural objects, inspired by the historic landscape. Analyses were based on field studies and literature review concerning the issue of workers' housing settlements and taking up the problem of evaluation and maintenance of historic buildings.

\section{STATE OF RESEARCH}

The oldest studies addressing the problems of housing development in the area of Upper Silesia come from the time of the industrial revolution. Such an example is the publication of Kurt Seidl, Der Arbeiterwohnungswesen in der Oberschlesien Montanindustrie. This book was published in 1913, at the initia- 
tive of the Upper Silesian Union of Industrialists of Mining and Metallurgy. ${ }^{2}$ Currently, the scope of the literature includes a number of publications, often based on the author's detailed spatial analysis on various aspects of workers' settlements. Analysis of architectural and urban structures are discussed in the works of: Dorota Głazek, Irma Nalepa-Orłowska, Alina Nowak-Lenartowska, Joanna Sokołowska-Mostowiak and Anna Sulimowska-Ociepka. There are many papers on the green areas associated with the industry, among others the works of: Krzysztof Gasidło, Aneta Dyraga, Martyna Walker and Katarzyna Łakomy. Characteristics of building complexes located in Katowice was included in the work of Lech Szaraniec.

\section{CONDITIONS}

The Industrial Revolution, which dates back to the eighteenth century, contributed to the rapid and uncontrolled development of housing centers. In many workplaces, workers have taken over the function of the machines, and the population began to settle en masse in urban areas. The result of the migration process was the chaotic thickening of buildings and deteriorating conditions of housing and sanitation. As a result of high demand for cheap residence, the phenomenon of land and housing speculation was formed. It was based on the construction of new residential buildings at the lowest cost. In many European cities, working-class districts are characterized by a drastically low standard, poverty and poor sanitation. ${ }^{3}$ Over time, the need to erect new housing for workers, characterized by the appropriate standard of buildings was a necessity because of the competitive conditions that prevailed in the Rhineland.

These types of problems have also appeared in the Upper Silesian Industrial District. Today, this area is the place with the highest concentration of industry in Poland, ${ }^{4}$ and in the $2^{\text {nd }}$ half of the $20^{\text {th }}$ century, it was still a region with a high degree of settlement in the vicinity of workplaces. ${ }^{5}$ Today's image of the cities within the scope of the Silesian Agglomeration is the result of many geographical, economic, social and political conditions. One of the main factors determining the formation of industrial basin in this area was the presence of productive

\footnotetext{
${ }^{2}$ Katarzyna Łakomy, "Pracownicze ogrody górnośląskich osiedli przemysłowych z przełomu XIX i XX wieku w świetle wybranych publikacji z epoki," Czasopismo Techniczne. Architektura 8 (2012): 191.

${ }^{3}$ Joanna Sokołowska-Mostowiak, "Idea miasta-ogrodu" na przykladach osiedli miast górnoślaskich (Gliwice: Wydawnictwo Politechniki Śląskiej, 2011), 14.

${ }^{4}$ Despite the fact that many changes have taken place.

${ }^{5}$ Alina Nowak-Lenartowska, Osiedla przyzakładowe jako problem urbanistyczny regionu: na przykładzie Górnoślaskiego Okręgu Przemystowego (Warszawa: Państwowe Wydawnictwo Naukowe, 1973), 5.
} 
mineral deposits, resulting from geological conditions. Of great importance in the process of populating the region was also the geographical location of Silesia at the junction of three different ethnic areas - Polish, Czech and German. ${ }^{6}$ The progressive industrialization and the influx of workers contributed to the creation of the first settlements with places of residence for people working in the mines and smelters. Development of buildings for workers was a process of transition from the most simple and primitive forms to the assumptions designed by German planners, modeled on ideas which were popular at that time. Today, workers' building complexes are a clear distinguishing feature of the cultural landscape of Upper Silesia, preserved and used until today, and deeply rooted in the history and traditions of the region.

\section{SELECTED WORKERS' HOUSING ESTATES IN THE MODERN LANDSCAPE OF THE UPPER SILESIAN CITIES}

Buildings for workers in the industrial area of Silesia have changed in their historical development. When reviewing the typology of this specific form of housing, one can observe the process of evolution from the most makeshift facilities to the solutions inspired by Western realizations, executed with attention to an adequate standard of use, location and transport links with the workplace and aesthetic and artistic value of buildings. Very often the settlements resulting in Silesia were an example of the most modern residential complexes, built with the use of new technologies and solutions. Despite wide variation between different types of buildings, some of them clearly inscribed in the landscape of many Upper Silesian towns, today forming a distinctive and legible mark in the landscape. An example of this type are the so called familoki, block buildings of the second half of the nineteenth century, modeled on barrack objects/houses. These were buildings on a rectangular plan, with a height of two or three facades, covered with gable roofs. These objects are characterized by brick facade and distinctive window and door lintels in the form of segmental arches. Bay windows are often painted red. Initially, these buildings were devoid of decoration, while in the later works ornaments of different colors of brick were used and pitched roofs were replaced with half hipped or mansard roofs. ${ }^{7}$

Familoki are a characteristic element of landscape composition of both of the discussed settlements. Workers' housing estate in Katowice-Załęże was established in the second half of the $19^{\text {th }}$ century for the workers of the "Kleofas"

\footnotetext{
${ }^{6}$ Paweł Rybicki, "Rozwój ludności Górnego Śląska od początku XIX wieku do pierwszej wojny światowej," in Górny Ślask: Prace i materiały geograficzne, ed. Antoni Wrzosek (Kraków: Wydawnictwo Literackie, 1955), 253.

${ }^{7}$ Anna Sulimowska-Ociepka, "Osiedla patronackie Górnego Śląska. Studium miejsca oraz znaczenie kultury przemysłowej w przestrzeni zurbanizowanej," (doctoral thesis, Silesian University of Technology, 2004), 138.
} 
mine. ${ }^{8}$ Now, it is located in the north-western part of the city and covers an area of 339 ha. From the south, the estate directly borders with the railway line, and on the north with intercity road. Both routes are heavily used by residents of the agglomeration, who daily commute to the center of Katowice from other cities, among others Gliwice, Zabrze, Ruda Śląska and Chorzów. Houses located there, although they do not create an express urban composition, however, in accordance with the theories of urban planning of the city Katowice, testify to the attractiveness of the area. ${ }^{9}$ Some of them are characterized by varied ornament and detail, affecting the artistic expression of architecture. In the urban structure of this settlement there is also a large amount of green areas of nonorganized character and economic buildings.
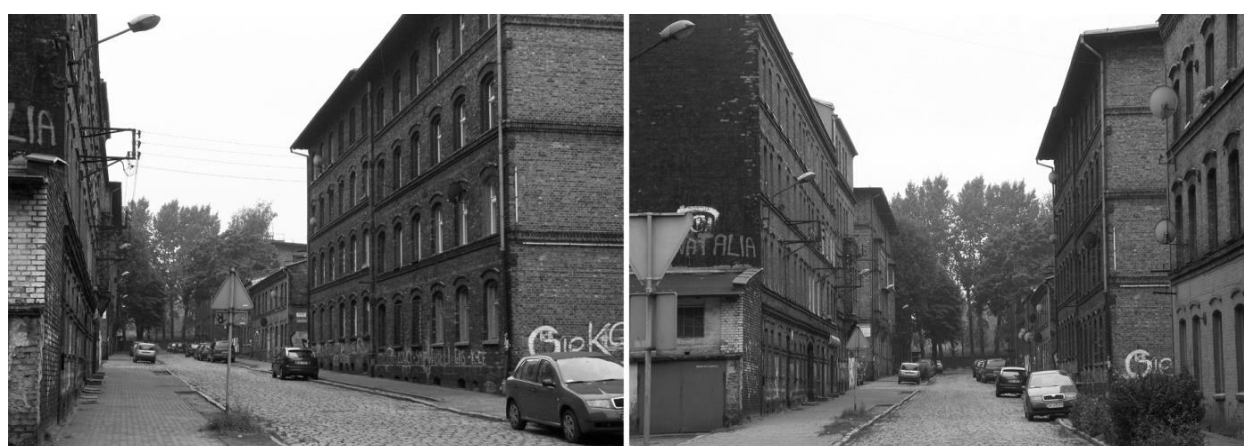

Fig. 1, 2. Workers' housing estate in Katowice-Załęże. Photo by Ewa Waryś, 2016.

The second of the discussed settlements, Nikiszowiec, is located in the south-eastern part of the city in Janów-Nikiszowiec district. The estate is away from both the city center as well as the major transportation routes. Nikiszowiec, next to Giszowiec, is the second residential estate commissioned by the company Georg von Giesches Erben and designed by the cousins Emil Zillmann and Georg Zillmann. ${ }^{10}$ A characteristic feature of the landscape of the estate is its unique architectural composition, resulting from the characteristic grouping of individual houses in nine distinct quarters. In addition to residential buildings, in the composition of the estate there is also a neo-baroque church, public buildings, a small park and the buildings of the mine. The entire building complex stands out because of the distinctive architectural buildings of brick

\footnotetext{
${ }^{8}$ Lech Szaraniec, Osady i osiedla Katowic (Katowice: Wydawnictwo Śląsk, 1984), 197.

${ }^{9}$ Katowice City Council, Studium Uwarunkowań i Kierunków Zagospodarowania Przestrzennego Miasta Katowice, part I, Uwarunkowania zagospodarowania przestrzennego, attachment 1 to Resolution XXI / 483/12 (25.04.2012), 66.

${ }^{10}$ They came from Meseritz (in Polish Międzyrzecze) and lived in Charlottenburg (from 1920 it was a district of Berlin).
} 
elevations, unified in terms of dimensions and materials used, but varied in terms of architectural details, among others bay windows, arches above the window and door openings and entrance portals. ${ }^{11}$ A typical feature of the estate are also red bay windows designating a rhythm in the architectural composition. One of the most interesting objects in the landscape of Nikiszowiec is a post office building, with its characteristic rose mosaic, which is a historical example of the introduction of elements of art into the cityscape.

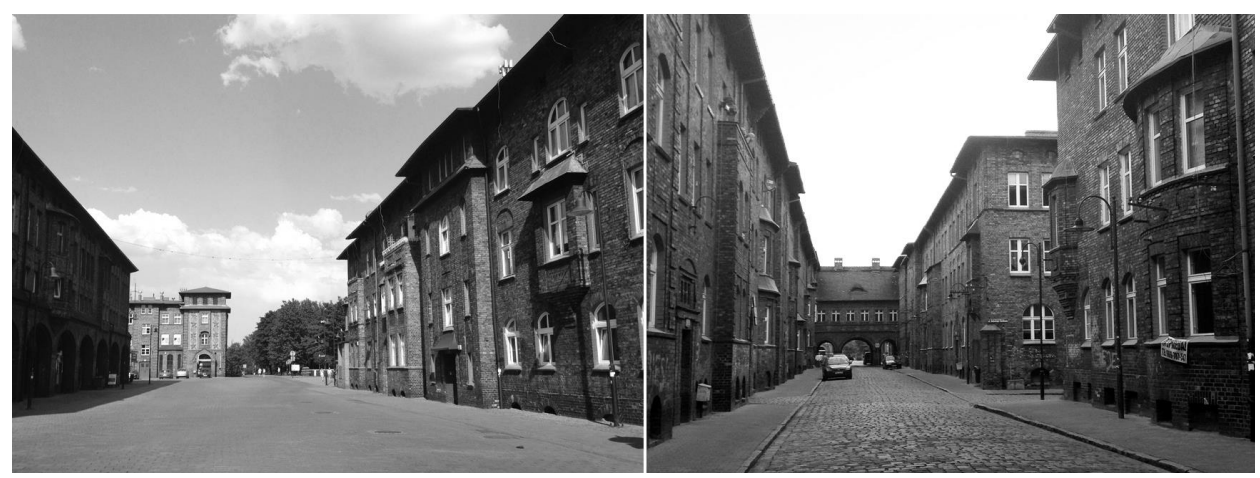

Fig. 3, 4. Post office building and familoki in Nikiszowiec. Photo by Ewa Waryś, 2016.

The factor that marks a distinction between the two building complexes is the condition of the settlements, and used forms of protection. Nikiszowiec is one of the few settlements of workers, which has survived to the present day in almost unchanged shape and spatial situation. ${ }^{12}$ It has been under legal protection in the form of an entry in the register of monuments and recognized as a Historic Monument. ${ }^{13}$ Every year, Nikiszowiec is the site of many special events (there are organized among others Miner's Day ${ }^{14}$ celebrations and Christmas fairs), and some of the apartments in historic buildings have been renovated and converted into modern apartments. This type of action, although sometimes are taken mainly for commercial reasons, are evidence of the

\footnotetext{
11 Maria J. Żychowska, "Budowanie według Witruwiusza - Nikiszowiec," Czasopismo Techniczne. Architektura 1 (2009): 163-164.

${ }^{12}$ Ibidem, 161.

${ }^{13}$ Historic Monument (Polish: Pomnik Historii) is one of several categories of objects of cultural heritage in Poland, one endowed with special presitge. The list of Historic Monuments comprises today circa 100 objects: achitectural and urban complexes, historical and archeological sites located in various regions in Poland. To be recognized as a Polish Historic Monument, an object must be declared such by the President of Poland. Nikiszowiec was established as a Historic Monument in 2011.

${ }^{14}$ This is Miner's Day called Barbórka in Poland, which takes place on December 4. Other known Coal Miners Day dates are December 6 and May 4.
} 
growing awareness of the value of this type of building complexes and their potential among others in cultural tourism.

However, it is a unique example, it is a rarity in the region. Comparing the current state of preservation of the settlement with the Katowice-Załęże building complex, one may notice enormous differences, resulting mainly from the state of individual buildings as well as land use in public spaces. The clearest errors and omissions, which occurred on the estate in Katowice-Załęże is primarily the poor state of preservation of architectural objects, a large number of defects, graffiti disfiguring elevations and different forms of the superstructure, which, through the materials used do not match the historical objects. Another missing part is proper management of public space, through the appointment of suitable zones (among others parking spaces) and the introduction of forms of greenery. Unfortunately, this housing estate is one of many examples of the condition of workers' houses in Upper Silesia.

\section{MODERN FORMS OF ARTISTIC EXPRESSION IN THE LANDSCAPES OF HISTORICAL HOUSING ESTATES}

Today, despite the extreme differences in the state of preservation of architectural objects and the forms of protection, the two discussed areas are places that show various forms of contemporary art. In Katowice-Załęże interesting forms of street art are created, often as an expression of opposition to the current economic situation in the region and the changes taking place. Such an example was the mural, which was created on the wall of one of the buildings within the Katowice Street Art Festival. Mural made by Łukasz Surowiec was a reproduction of a drawing of a five-year old girl who drew it for her father, after a wave of mining protests that swept through Silesia in the winter of 2015. On the figure, a red inscription stood out: Tato nie placz, Zosia [Daddy do not cry. Zosia], mapping the original children's spelling.

Unfortunately these examples of contemporary art, despite the fact that more and more often they appear in areas of historic settlements, however, are not permanent, and often disappear in the midst of aggressive forms of abusive graffiti and inscriptions, which are an example of the devastation of historic buildings. ${ }^{15}$

\footnotetext{
15 See BED, “Tato, nie płacz. Poruszający mural powstał w Załężu," Gazeta Wyborcza/Katowice 18.06.2015, http://katowice.wyborcza.pl/katowice/1,35063,18141781,_Tatonie_placz Porusza jacy_mural_powstal_w_Zalezu.html.
} 


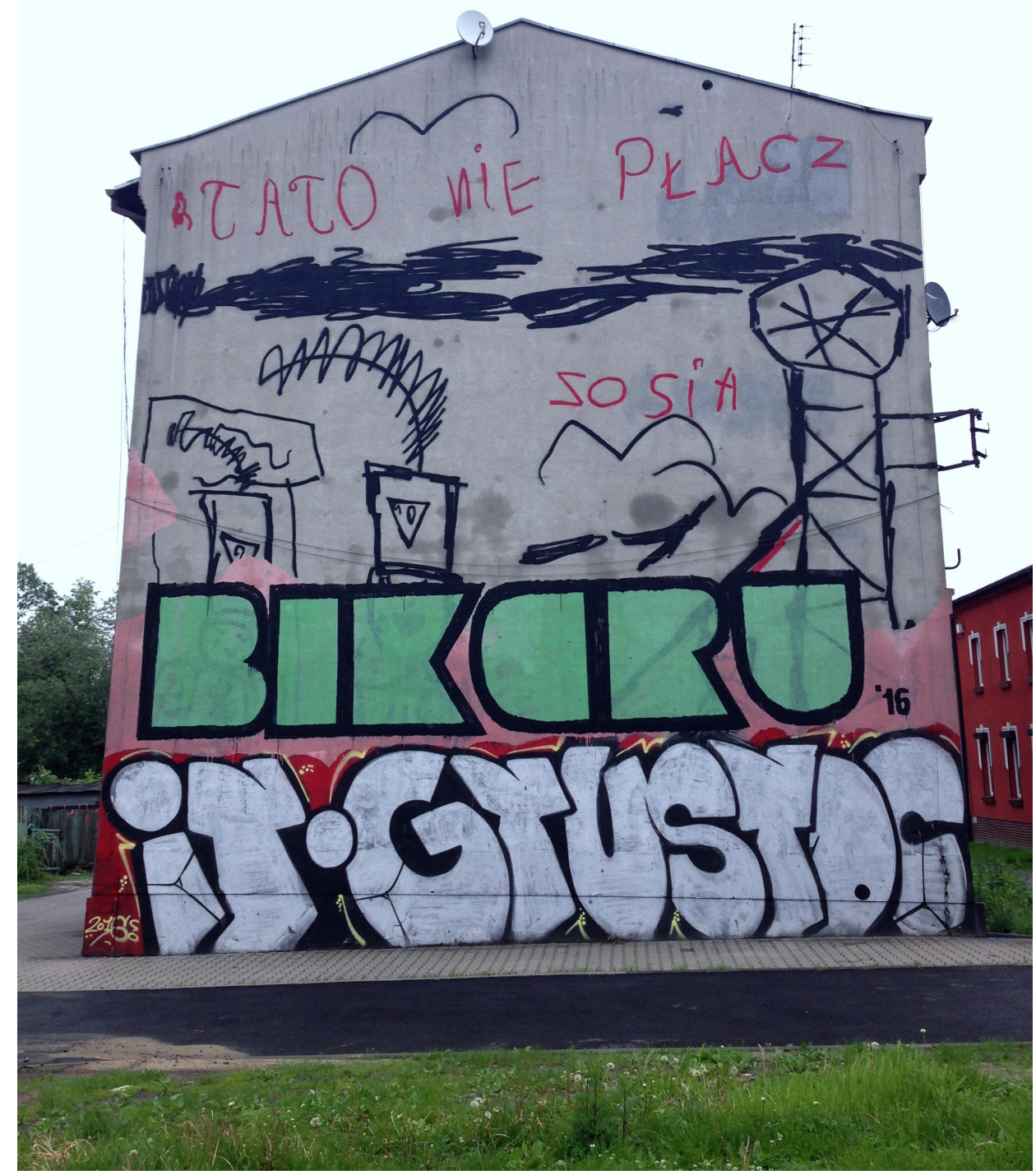

Fig. 5. Tato nie płacz, Zosia, mural by Łukasz Surowiec, based on drawing by Zofia Tabiś-Hubki, 2015, Katowice-Załęże, 14 Kupca Street. Current view shows the mural partially destroyed by graffiti writers. Photo by Ewa Waryś.

Contemporary art also appears in the landscape of the historic Nikiszowiec. Such an example was a temporary art installation with white balloons, which covered the facades of buildings in the context of the "Industriada" in 2012. Although the introduction of more sustainable activities is limited due to the 
restrictive forms of protection, however, artistic expression of Nikiszowiec is readable, and for many contemporary creators of art and culture this place is a source of inspiration. Movies of Kazimierz Kutz and amphitheater urban layout of the estate give it the scenography potential. Another area of artistic creativity, where the inspiration with this settlement is clear is the modern architecture of Katowice. The most representative example is the new building of the National Polish Radio Symphony Orchestra (NOSPR) ${ }^{16}$ where references to the historic landscape are reflected in the materials used and the red glyphs of window openings, referring to the color of the historical settlements. ${ }^{17}$

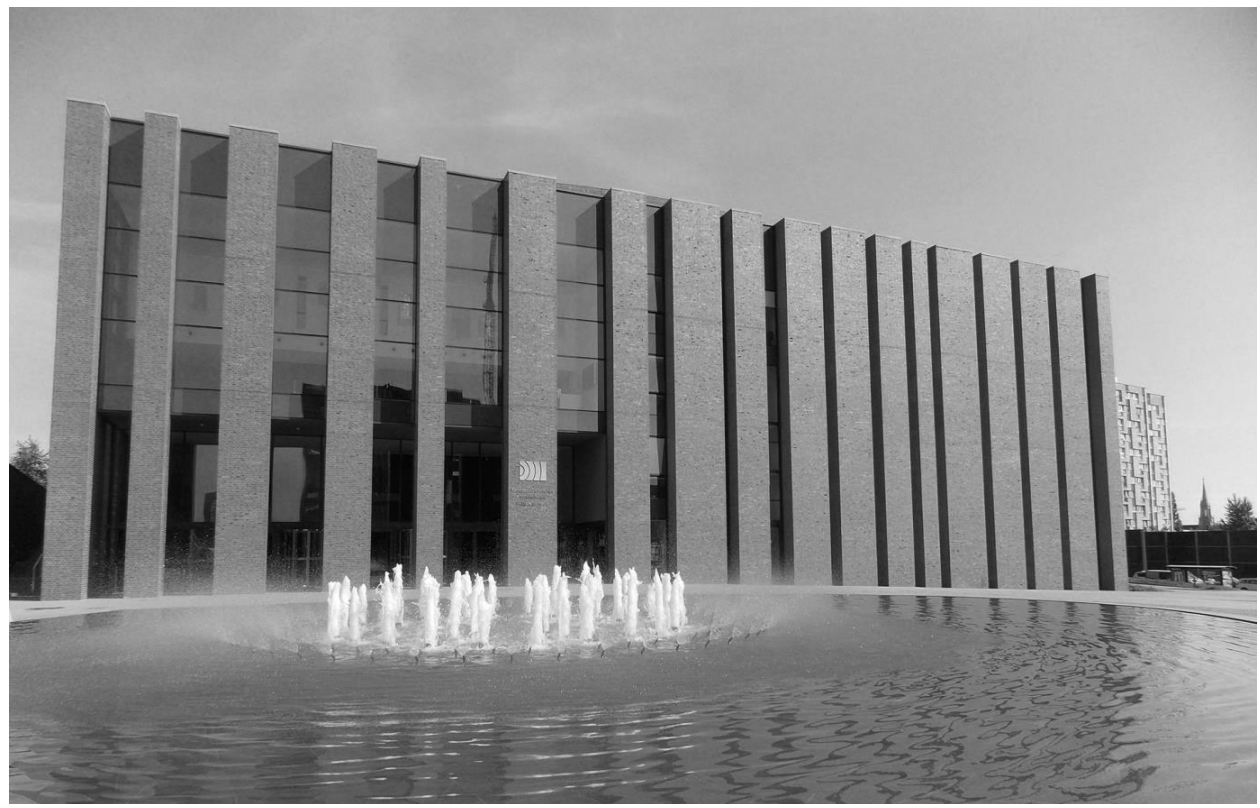

Fig. 6. Building of NOSPR, inspired by the landscape of Nikiszowiec. Photo by Ewa Waryś, 2015.

\section{SUMMARY AND CONCLUSIONS}

Today, the differences in the state of preservation of historical workers' settlements in Upper Silesia are reflected in the functioning and operation of entire residential neighborhoods. Although the diversity of the landscape of the compared settlements seems obvious, it is a problem which is also evident in the untapped potential of the estate in Katowice-Załęże, its wasted artistic values and lack of attention to the aesthetics of the historic buildings.

\footnotetext{
${ }^{16}$ NOSPR - Narodowa Orkiestra Symfoniczna Polskiego Radia [National Polish Radio Symphony Orchestra].

${ }^{17}$ Krzysztof Mycielski, “Bogactwo odniesień,” Architektura-murator 243 (12), (2014): 6.
} 


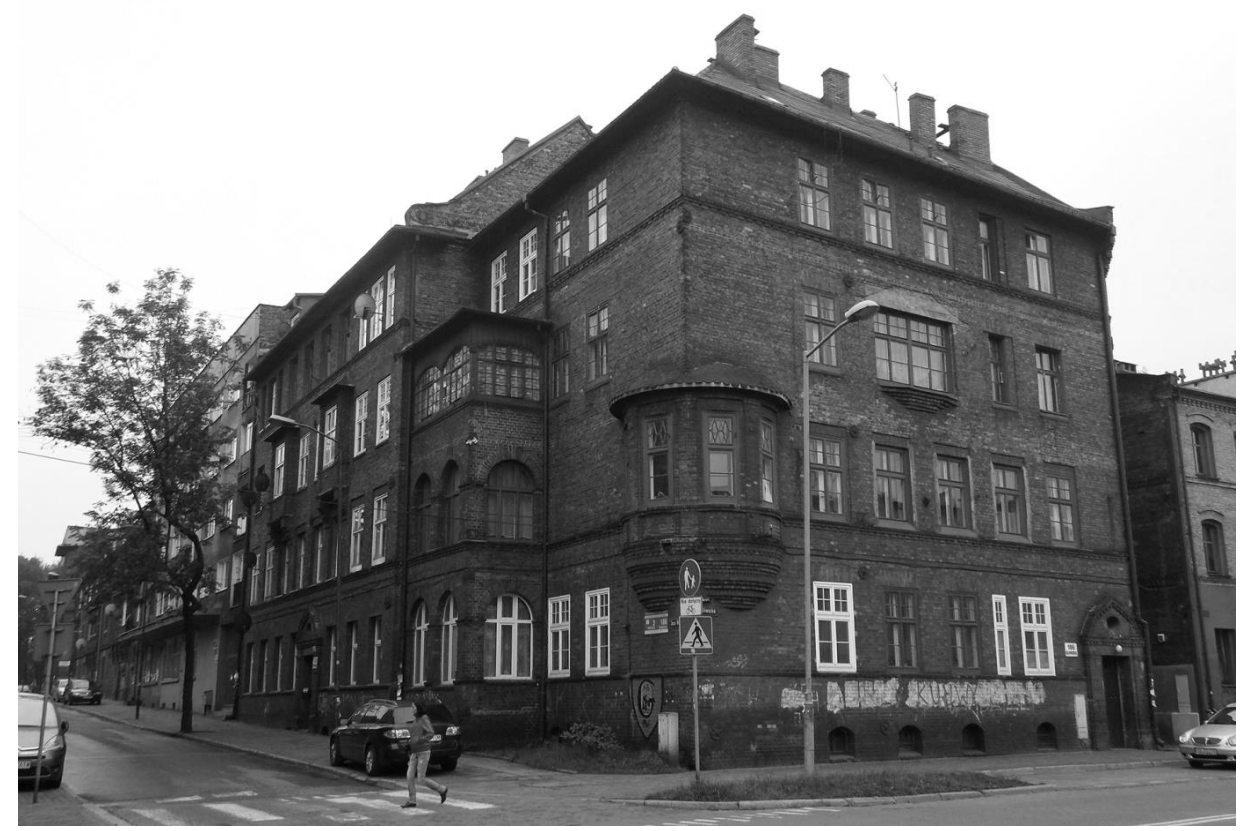

Fig. 7. Historical buildings in housing estate in Katowice-Załęże. Photo by Ewa Waryś, 2016.

In times of a gradual moving away from the old tradition of the workers' culture and the domination of new industries, many apartments, which once served to workers in mines and factories, have now been allocated to social housing. As a result of economic change and the failure or lack of regeneration programs, they have become places widely considered to be worthless, unattractive and dangerous. Today, their disastrous state of preservation and simultaneous location close to city centers and major transport routes, adversely affect the overall perception of the region. Only a few cases (such as Katowice Nikiszowiec), gained the rank of a symbol and architectural work, becoming an important destination for both locals and tourists.

The artistic value of the historical building complexes located in the cities of the Upper Silesian Agglomeration results from the diverse architectural detail, proper handling of color (among others red color recesses windows integrated into the brick facades) and care to maintain the correct proportions, both between individual elements of individual buildings, as well as the components of the entire urban structure, including buildings and green areas. The distinctive architectural design and simultaneous harmony of composition of larger urban structures prove the artistic expression of all complexes. Their value, though obvious often disappears, and it is difficult to discern because of the poor condition of individual settlements. The perception of these places is associated 
with age-old philosophical dispute between subjective and objective understanding of aesthetics, while the perception of hidden value is related to finding compounds with the tradition of the place (genius loci) and the culture and history of the region. ${ }^{18}$

\section{BIBLIOGRAPHY}

BED. “Tato, nie płacz. Poruszający mural powstał w Załężu," Gazeta Wyborcza/Katowice 18.06.2015, http://katowice.wyborcza.pl/katowice/1,35063,18141781,_Tato_nie_placz Po ruszajacy_mural_powstal_w_Zalezu.html.

Katowice City Council. Studium Uwarunkowań i Kierunków Zagospodarowania Przestrzennego Miasta Katowice, part 1 Uwarunkowania zagospodarowania przestrzennego, attachment 1 to Resolution no. XXI / 483/12, 25.04.2012.

Łakomy, Katarzyna. "Pracownicze ogrody górnośląskich osiedli przemysłowych z przełomu XIX i XX wieku w świetle wybranych publikacji z epoki." Czasopismo Techniczne. Architektura 8 (2012): 187-196.

Mycielski, Krzysztof. “Bogactwo odniesień,” Architektura-murator 243 (12) (2014).

Nowak-Lenartowska, Alina. Osiedla przyzakładowe jako problem urbanistyczny regionu: na przykładzie Górnoślaskiego Okręgu Przemysłowego. Warszawa: Państwowe Wydawnictwo Naukowe, 1973.

Rybicki, Paweł. "Rozwój ludności Górnego Śląska od początku XIX wieku do pierwszej wojny światowej." In Górny Śląsk: Prace i materiaty geograficzne, edited by Antoni Wrzosek. Kraków: Wydawnictwo Literackie, 1955.

Sokołowska-Mostowiak, Joanna. "Idea miasta-ogrodu" na przykładach osiedli miast górnoślaskich. Gliwice: Wydawnictwo Politechniki Śląskiej, 2011.

Sulimowska-Ociepka, Anna. "Osiedla patronackie Górnego Śląska. Studium miejsca oraz znaczenie kultury przemysłowej w przestrzeni zurbanizowanej." Doctoral thesis, Silesian University of Technology, 2004.

Szaraniec, Lech. Osady i osiedla Katowic. Katowice: Wydawnictwo Śląsk, 1984.

Szczypka-Gwazda, Barbara. Pomiędzy praktyka a utopią: trójmiasto Bytom - Zabrze - Gliwice jako przykład koncepcji miasta przemysłowego czasów Republiki Weimarskiej. Katowice: Wydawnictwo Uniwersytetu Śląskiego, 2003.

Tatarkiewicz, Władysław. Historia estetyki 3. Estetyka nowożytna, Warszawa: Arkady, 1991.

Żychowska, J. Maria. "Budowanie według Witruwiusza - Nikiszowiec.” Czasopismo Techniczne. Architektura 1 (2009): 161-165.

\footnotetext{
${ }^{18}$ Władysław Tatarkiewicz, Historia estetyki 3. Estetyka nowożytna, (Warszawa: Arkady, 1991), 383-389.
} 